\section{Pulsed Excimer Laser Radiation Influences in Vitro Culture of Algerian Ivy}

\section{Karim H. Al-Juboory ${ }^{1}$, David J. Williams ${ }^{1}$, and Munir H. Nayfeh ${ }^{2}$ University of Illinois, Urbana, IL 61801}

Additional index words. growth regulator, microshoot, tissue culture, Hedera canariensis

Use of gamma rays and $\mathrm{X}$ rays with in vitro cultures has been used to isolate unique plant types (Chevreau et al., 1989). Exposure of in vitro cultures to gamma and X-ray radiation has resulted in the mutagenesis of grape (Kim et al., 1989) and reduced regeneration of maize lants (Moustafa et al., 1989). Our study was initiated to find an alternative method for the elimination of biological contaminants from in vitro cultures of Algerian ivy (Hedera canariensis L.).

One-node explants of juvenile Algerian ivy were washed for $1 \mathrm{~min}$ in a $0.1(\mathrm{w} / \mathrm{v}) \mathrm{Al}$ conox solution, rinsed with sterile distilled water (SDW), soaked for $5 \mathrm{sec}$ in $70 \%$ ethanol, rinsed with SDW, and soaked for $15 \mathrm{~min}$ in a $0.5 \% \mathrm{NaOCl}$ solution containing $0.1 \%(\mathrm{v} / \mathrm{v})$ Tween 20. Nodal segments were then rinsed three times ( 5 min each) with SDW and aseptically separated into 1.5 to 2.0-cm sections, each one containing a bud.

Explants were placed on modified Murashige and Skoog (1962) medium (MS). Before autoclaving, the bactericide gentamicin sulfate was added at $3 \mathrm{mg} \cdot$ liter $^{-1}$. The $\mathrm{pH}$ was adjusted to 5.7 and agar ( $\left.7 \mathrm{~g} \cdot \mathrm{liter}^{-1}\right)$ was added. The medium was autoclaved at $120 \mathrm{C}$ for $15 \mathrm{~min}$. A single microshoot was placed into a $25 \times 150$-mm culture tube containing $15 \mathrm{ml}$ of medium. Cultures were incubated

Received for publication 6 Aug. 1990. The cost of publishing this paper was defrayed in part by the payment of page charges. Under postal regulations, this paper therefore must be hereby marked advertisement solely to indicate this fact:

Dept. of Horticulture, 1201 S. Dorner Dr.

${ }^{2}$ Dept. of Physics, 407 Loomis Lab. at $25 \mathrm{C}$ with a $16-\mathrm{h}$ photoperiod of 40 to 60 $\mu \mathrm{mol} \cdot \mathrm{m}^{-2} \cdot \mathrm{s}^{-1}$ provided by cool-white fluorescent lamps. The explants were maintained for 1 month on MS medium. One day after explanting, the cultures were treated with 50 pulses of radiation from a $\mathrm{XeCl}$ excimer laser (Series 2000 excimer laser; Questek, Billerica, Mass.) of 308-nm wavelength at $0,100,200$, and $300 \mathrm{~mJ} /$ pulse corresponding to a power density of $1.6 \times 10^{6} \mathrm{~W} \cdot \mathrm{cm} 2$. The output was pulsed with a 20 -ns pulse duration in a rectangular beam shape of $1 \times$ $3 \mathrm{~cm}$. The percentage of contaminated cultures, petiole length, leaf count, and root count were determined 30 days after the laser treatment. Leaf area was determined with an electronic area meter (Model LI-3100; LICOR, Lincoln, Neb.).

The experiment consisted of 24 single-explant replicates per treatment arranged in a completely randomized design. Data were subjected to analysis of variance, and all proportional data were transformed into arcsin values before analysis. Data were tested by the General Linear Model Procedure and regression analysis (SAS Institute. 1985).

Ninety percent of the control cultures of Algerian ivy were contaminated 4 days after culturing (Table 1). Cultures treated with 50 pulses of $100 \mathrm{~mJ} \mathrm{XeCl}$ excimer laser radiation had $10 \%$ contamination, whereas cultures treated with higher doses were not contaminated. Initially, growth of plantlets originating from irradiated explants appeared elongated, although this effect was only temporary and subsequent growth appeared normal. The laser radiation increased petiole length, leaf area and count, root count, and overall plant growth of Algerian ivy. The reasons for increased growth need further investigation. Development of a simple radiation system would provide researchers and plant propagators with a tool for decontamination of in vitro cultures.

\section{Literature Cited}

Chevreau, E., L. Decourtype, and R.M. Skirvin. 1989. A review of pear chimeras: Their identification and separation into pure types. HortScience 24:32-34.

Kim, S.K., J.K. Hwang, K.C. Ko, and Y.I. Lee. 1989. In vitro growth and mutagenesis of grape shoot tips as affected by chemical and physical mutagens. Kor. Soc. Hort. Sci. 7:140-141.

Murashige, T. and F. Skoog. 1962. A revised medium for rapid growth and bioassays with tobacco tissue cultures. Physiol. Plant. 15:473476.

Moustafa, R.A.K., D.R. Duncan, and J.M. Widholm. 1989. The effect of gamma radiation and N-ethyl-N-nitrosourea on cultured maize callus growth and plant regeneration. Plant Cell Tissue Organ Culture 17:121-132.

SAS Institute, Inc. 1985. SAS user's guide: Statistics, SAS Institute, Cary, N.C.

Table 1. Effect of pulsed excimer laser radiation on growth characteristics and root count of Algerian ivy grown in vitro as evaluated 30 days after treatment $(n=24)$.

\begin{tabular}{lccccc}
\hline \hline $\begin{array}{c}\text { Treatment } \\
(\mathrm{mJ})\end{array}$ & $\begin{array}{c}\text { Contamination } \\
(\%)\end{array}$ & $\begin{array}{c}\text { Petiole } \\
\text { length } \\
(\mathrm{mm})\end{array}$ & $\begin{array}{c}\text { Leaf } \\
\text { area }\end{array}$ & $\begin{array}{c}\text { Leaf } \\
\text { count }\end{array}$ & $\begin{array}{c}\text { Root } \\
\text { count }\end{array}$ \\
\hline 0 & 90.0 & 4.0 & 2.0 & 1.0 & 0.0 \\
100 & 10.0 & 20.0 & 5.2 & 3.0 & 1.0 \\
200 & 0.0 & 21.2 & 5.6 & 3.0 & 1.0 \\
300 & 0.0 & 22.0 & 6.3 & 3.0 & 1.0 \\
Significance & $\mathrm{I}^{*}, \mathrm{Q}^{* *}$ & $\mathrm{~L}^{*}, \mathrm{Q}^{* *}$ & $\mathrm{~L}^{*}, \mathrm{Q}^{* *}$ & $\mathrm{~L}^{*}, \mathrm{Q}^{* *}$ & $\mathrm{~L}^{*}, \mathrm{Q}^{* *}$ \\
\hline
\end{tabular}

****Significant at $P=0.05$ or 0.001 , respectively. $\mathrm{L}=$ linear and $\mathrm{Q}=$ quadratic trends. 